\title{
Kualitas Spermatozoa Domba yang Disentrifugasi sebelum Dibekukan dengan Pengencer Laktosa Pasca-Thawing
}

\author{
(Quality of Post-thawed Centrifugated Ram Sperm Before Freezing with Lactose Extender) \\ Latifah Humairoh, Ni Wayan Kurniani Karja* \\ Bagian Reproduksi dan Kebidanan, Departemen Klinik Reproduksi dan Patologi, \\ Fakultas Kedokteran Hewan, Institut Pertanian Bogor \\ Jl. Agatis Kampus IPB Dramaga Bogor, 16680. \\ *Penulis untuk korespondensi: karjanwk13@gmail.com \\ Diterima 28 Oktober 2013, Disetujui 23 Desember 2013
}

\begin{abstract}
ABSTRAK
Telah diketahui bahwa plasma semen dapat menurunkan motilitas spermatozoa selama proses pembekuan. Sentrifugasi adalah metode yang digunakan untuk memisahkan plasma semen pada spermatozoa. Oleh karena itu, dilakukan penelitian pada spermatozoa domba yang dibekukan dan diberi perlakuan sentrifugasi untuk memisahkan plasma semen dan spermatozoa domba. Terdapat tiga perlakuan pada sampel spermatozoa domba yaitu kontrol (tanpa sentrifugas) dan sentrifugasi dilakukan selama 5 menit dan 10 menit dengan kecepatan 3000 rpm. Ketiga sampel diekuilibrasi selama 2 jam pada suhu $4{ }^{\circ} \mathrm{C}$, kemudian dibekukan dengan nitrogen cair dan di thawing pada suhu $37{ }^{\circ} \mathrm{C}$ selama 30 detik. Hasil yang didapat dengan menggunakan program analisis data SPSS dengan Anova dan uji lanjut Duncan menunjukkan bahwa tidak ada perbedaan nyata pada motilitas, viabilitas, dan integritas membran plasma utuh (MPU) antara spermatozoa dari kelompok kontrol dan perlakuan setelah thawing $(P>0,05)$. Dari data tersebut dapat disimpulkan bahwa keberadaan plasma semen selama proses pembekuan tidak mempunyai pengaruh negatif terhadap kualitas spermatozoa domba pasca pembekuan.
\end{abstract}

Kata kunci: domba, pembekuan, sentrifugasi, spermatozoa

\begin{abstract}
It has been known that seminal plasma (SP) can be deleterious for sperm motility while freezing. Centrifugation is a method to remove seminal plasma from sperm. The aim of this research is to get better quality of frozen-thawed ram sperm by removed the seminal plasma. In this research, ram semen were centrifuged for 5 minutes and 10 minutes at $3000 \mathrm{rpm}(480 \mathrm{~g})$ and non-centrifuged semen was used as control. After that, semen were equilibrated for 2 hours at temperatur $4{ }^{\circ} \mathrm{C}$ and freezed with liquid nitrogen then thawed at $37{ }^{\circ} \mathrm{C}$ for 30 seconds. The effects of treatment on motility, viability, and membran integrity was determined using SPSS analysis program with Anova and Duncan's test. The result showed that there was no differences on motility, viability, and membran integrity after thawed $(p>0.05)$. Based on this result, we concluded that the existance of seminal plasma during cryopreservation did not have negative effects on post-thawed quality of ram sperm.
\end{abstract}

Key words: centrifugation, freezing, ram, sperm 


\section{PENDAHULUAN}

Sperma mamalia diproduksi oleh testis yang kemudian disalurkan ke epididimis dalam bentuk haploid. Sperma yang dikeluarkan dalam tubuh (fresh ejaculate) belum dapat dikatakan fertil atau dapat membuahi ovum apabila belum mengalami proses kapasitasi. Plasma semen yang merupakan bagian dari semen memiliki peranan penting dalam proses kapasitasi tersebut (Töpfer-Petersen et al., 2005). Plasma semen adalah campuran sekresi yang dihasilkan dari beberapa kelenjar pada saluran reproduksi jantan. Hampir sama dengan cairan tubuh lainnya, plasma semen mengandung protein dalam konsentrasi yang tinggi (Pilch dan Mann, 2006). Plasma semen berfungsi menjaga kestabilan dari membran plasma spermatozoa hingga kapasitasi dimulai di saluran reproduksi betina (Cross, 1996). Disisi lain dilaporkan bahwa konsentrasi plasma semen yang tinggi selama proses pendinginan dan penyimpanan dapat merusak spermatozoa (Pickett et al., 1975). Plasma semen juga dilaporkan dapat menghambat kapasitasi pada semen segar (Suzuki et al. 2002; Vadnais et al. 2005) dan semen beku babi (Vadnais et al., 2005). Pada kerbau, plasma semen mengandung faktor antimotilitas (Goyal et al., 1996) dan faktor spermiostatik (Ahmad et al., 1996) yang dapat menurunkan motilitas dan viabilitas postthawed spermatozoa. Kandungan lipid terutama asam lemak tak jenuh ganda pada plasma semen yang tinggi menyebabkan spermatozoa rentan terhadap reaksi peroksidasi sehingga memengaruhi ketahanan terhadap cold shock (White, 1993). Pemisahan spermatozoa dari plasma semen sebelum dibekukan dilaporkan dapat meningkatkankualitasspermatozoapasca thawing. Pemisahan plasma semen berkontribusi dalam kestabilan membran plasma selama dibekukan, meningkatkan kekebalan terhadap hypo-osmotic shock dan mengurangi respon terhadap reaksi akrosom (Barrier-Battut et al., 2010). Pemisahan spermatozoa dan plasma semen dapat dilakukan dengan cara sentrifugasi. Pada kuda, sentrifugasi menjaga persentase motilitas spermatozoa setelah dibekukan selama 48 jam (Brinsko et al., 2000). Selain itu pemisahan plasma semen berkontribusi terhadap stabilitas membran spermatozoa selama pendinginan, meningkatkan ketahanan spermatozoa terhadap kondisi hipoosmotik, dan mengurangi respon induksi farmakologis dari reaksi akrosom (Barrier-Battut et al., 2010). Berdasarkan sumber-sumber di atas, penelitian ini dilakukan untuk mengetahui pengaruh pemisahan plasma semen dengan sentrifugasi pada kualitas postthawed spermatozoa domba.

(c) 2014 Fakultas Kedokteran Hewan IPB

\section{BAHAN DAN METODE}

\section{Bahan Pengencer}

Pengencer yang digunakan dalam penelitian ini adalah Niwa-Sasaki Freezing Medium (NSF) (Kikuchi et al., 1999) Pengencer NSF ini terdiri atas dua bagian yaitu NSF 1 dengan komposisi laktosa $8.8 \%$, kuning telur $20 \%$, dan ampisilin $20 \mathrm{mg} / \mathrm{mL}$ dalam deionized water dan NSF 2 dengan komposisi NSF 1 92.52\%, OEP (Orvus ES Paste) 1.48\%, dan gliserol 6\%.

\section{Koleksi Semen Domba}

Semen dikoleksi dari seekor domba garut jantan sehat dengan umur 1-2 tahun yang diberi pakan hijauan dan konsentrat. Pengambilan semen dilakukan dua hari sekali. Koleksi semen dilakukan dengan menggunakan vagina buatan. Semen ditampung dua sampai tiga kali ejakulat yang kemudian dievaluasi di laboratorium.

\section{Sentrifugasi dan Pembekuan Semen}

Semen hasil koleksi segera dievaluasi motilitas, viabilitas dan integritas membran plasma utuh (MPU). Semen diencerkan dengan NSF1 kemudian dibagi dalam tiga tabung dengan volume sama. Kemudian semen disentrifugasi (EBA 20 Hettich zentrifugen) selama 5 menit dan 10 menit dengan kecepatan $3000 \mathrm{rpm}$. Setelah disentrifugasi supernatan dibuang kemudian ditambahkan NSF 1 hingga $2 \mathrm{~mL}$ dan dihomogenkan. Semen dievaluasi motilitas, viabilitas dan integritas membran plasma utuh (MPU) untuk yang kedua kalinya. Kemudian semen diekuilibrasi pada suhu $4{ }^{\circ} \mathrm{C}$ selama 2 jam. Setelah 2 jam, semen ditambahkan NSF 2 dengan 2 tahap. Setengah bagian NSF 2 dimasukkan terlebih dahulu pada tabung yang telah terisi semen+NSF 1 sebanyak $1 \mathrm{~mL}$. Setengah bagian lainnya ditambahkan 5 menit kemudian. Semen dimasukkan ke dalam straw dan diekuilibrasi pada uap nitrogen cair selama 20 menit. Dilanjutkan dengan dimasukkan dalam nitrogen cair untuk penyimpanan. Thawing dilakukan selama 30 detik pada suhu $32{ }^{\circ} \mathrm{C}$. Setelah itu semen dievaluasi motilitas, viabilitas dan integritas membran plasma utuh (MPU) untuk yang terakhir kali.

\section{Analisis Data}

Data yang diperoleh segera setelah koleksi, setelah sentrifugasi, dan setelah thawing disajikan dalam bentuk persentase. Hasil yang diperoleh dengan lima kali pengulangan dianalisis dengan menggunakan program analisis data SPSS 16 dengan Anova dan uji lanjut Duncan. 


\section{HASIL DAN PEMBAHASAN}

Dari penelitian yang dilakukan diperoleh motilitas spermatozoa segera setelah dikoleksi adalah $85 \%$. Segera setelah disentrifugasi persentase motilitas sperma pada kelompok control (tanpa sentrifugasi) lebih tinggi dibandingkan motilitas kelompok sperma yang disentrifugasi $(\mathrm{P}<0.05)(\mathrm{Ta}-$ bel 1). Hal ini menunjukkan bahwa setrifugasi memberikan pengaruh terhadap motilitas spermatozoa. Menurut Katila dan Kareskoski (2006) terlepas dari tujuan penghilangan plasma semen, sentrifugasi sendiri dapat merugikan karena kerusakan mekanis yang ditimbulkan. Pada penelitian ini, sentrifugasi pada semen domba dilakukan pada kecepatan 3000 rpm supaya plasma semen seluruhnya dapat dihilangkan. Pemilihan waktu selama 5 menit dan 10 menit sentrifugasi untuk mendapatkan hasil sentrifugasi yang optimal dan tidak adanya spermatozoa pada supernatan. Menurut Alvarez et al. (1993) bahwa kerusakan pada spermatozoa selama sentrifugasi dapat disebabkan efek mekanis langsung dari sentrifugasi yang memengaruhi membran spermatozoa.
Pemisahan plasma sperma dari plasma semen pada penelitian ini tidak memberikan pengaruh terhadap motilitas spermatozoa setelah dibekukan karena motilitas spermatozoa post-thawed tidak berbeda di antara kelompok perlakuan (Tabel 1) $(P>0.05)$. Walaupun banyak penelitian yang melaporkan bahwa pemisahan plasma semen sebelum proses pembekuan memberikan pengaruh yang baik terhadap motilitas spermatozoa post-thawing, salah satunya pada spermatozoa kuda (Brinsko et al., 2000) tetapi pada keledai, perlakuan sentrifugasi dalam proses pembekuan spermatozoa tidak menunjukkan pengaruh yang positif (Rota et al., 2008).

Menurut Rijsselaere et al. (2002) bahwa sentrifugasi menunjukkan dampak positif apabila terdapat penambahan pasta Equex STM dalam pengencer yang digunakan sehingga motilitas progresif dan viabilitas spermatozoa pada semen beku anjing dapat dipertahankan. Selain pada spermatozoa anjing juga dilakukan penelitian pada spermatozoa kuda oleh Moore et al. (2005) bahwa sentrifugasi untuk menghilangkan plasma semen, pada penyimpanan

Tabel 1 Motilitas spermatozoa domba setelah disentrifugasi sebelum dibekukan pasca thawing

\begin{tabular}{ccc}
\hline Kelompok (menit) & Setelah disentrifugasi $(\% \pm S D)$ & Setelah dibekukan $(\% \pm$ SD) \\
\hline 0 & $85,0 \pm 0^{\mathrm{a}}$ & $30,0 \pm 7.9$ \\
5 & $79,0 \pm 2.2^{\mathrm{b}}$ & $38,0 \pm 9,1$ \\
10 & $80,0 \pm 0^{\mathrm{b}}$ & $41,0 \pm 7,4$ \\
\hline
\end{tabular}

Superskrip huruf berbeda pada kolom yang sama menunjukkan berbeda nyata $(p<0,05)$, kelompok $0=$ kontrol, kelompok $5=$ sentrifugasi selama 5 menit, dan kelompok 10= sentrifugasi selama 10 menit.

Tabel 2 Viabilitas spermatozoa domba setelah disentrifugasi sebelum dibekukan pasca thawing

\begin{tabular}{ccc}
\hline Kelompok (menit) & Setelah disentrifugasi $(\% \pm$ SD) & Setelah dibekukan (\% \pm SD) \\
\hline 0 & $92,0 \pm 4,6$ & $74,0 \pm 7,0$ \\
5 & $91,0 \pm 3,4$ & $78,0 \pm 10,1$ \\
10 & $91,0 \pm 2,3$ & $81,0 \pm 10,0$ \\
\hline
\end{tabular}

Kelompok $0=$ kontrol, kelompok $5=$ sentrifugasi selama 5 menit, dan kelompok $10=$ sentrifugasi selama 10 menit.

Tabel 3 Integritas membran plasma utuh (MPU) spermatozoa domba setelah disentrifugasi sebelum dibekukan pasca thawing

\begin{tabular}{ccc}
\hline Kelompok (menit) & Setelah disentrifugasi $(\% \pm$ SD) & Setelah dibekukan $(\% \pm$ SD) \\
\hline 0 & $95,0 \pm 2,9$ & $85,0 \pm 7,7$ \\
5 & $96,0 \pm 1,5$ & $91,0 \pm 1,8$ \\
10 & $92,0 \pm 1,5$ & $91,0 \pm 2,1$ \\
\hline
\end{tabular}

Kelompok $0=$ kontrol, kelompok $5=$ sentrifugasi selama 5 menit, dan kelompok $10=$ sentrifugasi selama 10 menit. 
jangka pendek plasma semen tidak akan menimbulkan efek yang signifikan terhadap motilitas spermatozoa tetapi apabila semen disimpan dalam jangka waktu lama maka akan menimbulkan efek yang dapat merusak spermatozoa tersebut.

Hasil yang didapat dari penelitian, menunjukkan bahwa tidak adanya perbedaan nyata selain pada motilitas spermatozoa kontrol dengan setelah disentrifugasi dimungkinkan karena semen kontrol adalah semen segar yang belum mendapatkan perlakuan apapun. Dalam penelitian Schäfer-Somi et al. (2006) mereka menyimpulkan bahwa pembekuan dengan menggunakan suhu yang sangat rendah pada awal prosedur dapat mencegah kerusakan membran karena pembentukan kristal es.

Viabilitas spermatozoa segera setelah dikoleksi adalah 92\%. Proses sentrifugasi tidak berpengaruh terhadap viabilitas spermatozoa karena viabilitas spermatozoa segera setelah sentrifugasi dan setelah dibekukan tidak berbeda di antara kelompok perlakuan (Tabel 2) ( $P>0.05)$. Len et al. (2010) melaporkan bahwa sentrifugasi pada kecepatan $400 \mathrm{~g}$ maupun $900 \mathrm{~g}$ tidak memiliki pengaruh yang nyata terhadap viabilitas spermatozoa kuda setelah dibekukan. Meskipun konsentrasi plasma semen yang tinggi dapat menurunkan viabilitas spermatozoa pada beberapa spesies. Namun pada Ilama, viabilitas spermatozoa tidak berbeda nyata antara semen yang diencerkan dan tidak diencerkan (Giuliano et al., 2010). Hasil viabilitas yang lebih baik didapat dengan tetap mempertahankan keberadaan plasma semen atau ketika semen tidak diencerkan. Hampir sama dengan rusa, plasma semen sangat menguntungkan untuk menjaga viabilitas spermatozoa (Martinez-Pastor et al., 2006).

Hasil rataan intergritas membran plasma utuh (MPU) spermatozoa pada semen segar adalah 94.8\%. Integritas membran plasma utuh (MPU) baik setelah sentrifugasi dan post-thawing tidak menunjukkan perbedaan yang nyata $(P>0.05)$ (Tabel 3). Hal ini berlawanan dengan penelitian Barrier-Battut et al. (2010) yaitu persentase intergritas membran plasma utuh didapat hasil yang lebih baik pada sampel dengan sentrifugasi. Penghilangan plasma semen sebelum dibekukan berkontribusi pada stabiltas membran spermatozoa. Meningkatkan kekebalan terhadap hypo-osmotic shock dan mengurangi respon terhadap reaksi akrosom. Akan tetapi, sentrifugasi tidak memengaruhi motilitas. Rota et al. (2008) penelitian yang dilakukan pada spermatozoa keledai juga menunjukkan bahwa penghilangan plasma semen selama pembuatan semen beku tidak terlalu menguntungkan. Hal ini dikarenakan persentase tertinggi motilitas total dan spermatozoa motil didapat pada spermatozoa tanpa sentrifugasi.

\section{UCAPAN TERIMAKASIH}

Penelitian ini sebagian didanai oleh Hibah Bersaing Institut Pertanian Bogor No.15/13.24.4/SPP/ PHB/2011 a.n. NWK.

"Penulis menyatakan tidak ada konflik kepentingan dengan pihak-pihak yang terkait dalam penelitian ini"

\section{DAFTAR PUSTAKA}

Ahmad M, Khan A, Shah ZA, Ahmad KM. 1996. Effect of removal of seminal plasma on the survival rate of buffalo bull spermatozoa. Animal Reproduction Science 41: 193-199.

Alvarez JG, Lasso JL, Blasco L, Nunez RC, Heyner S, Caballero P, Storey BT. 1993. Centifugation of human spermatozoa induces sublethal damage; separation of human spermatozoa from seminal plasma by dextran swim-up procedure without centrifugation extends their motile life. Human Reproduction 8: 1087-1092.

Barrier-Battut L, Bonnet C, Giraudo A, Dubois C, Caillaud M, Vidament M. 2010. Removal of seminal plasma by centrifugation, before cooled storage, enhances membrane stability of stallion spermatozoa. Animal Reproduction Science S189-190.

Brinsko SP, Crockett EC, Squires EL. 2000. Effect of centrifugation and partial removal seminal plasma on equine spermatozoa motility after cooling and storage. Theriogenology 54: 129-136.

Cross NL. 1996. Human seminal plasma prevents sperm from becoming acrosomally responsive to the agonist, progesterone: cholesterol is the major inhibitor. Biology of Reproduction 54: 138145.

Giuliano S, Carretero M, Gambarotta M, Neild D, Trasorras V, Pinto M, Miragaya M. 2010. Improvement of llama (lama glama) seminal characteristics using collagenase. Animal Reproduction Science 18: 98-102.

Goyal RL, Tuli RK, Georgie GC, Chand D. 1996.Comparison of quality and freezability of water buffalo semen after washing or sephadex filtration. Theriogenology 46: 679-686.

Katila T, Kareskoski M. 2006. Component of stallion seminal plasma and their influence on spermatozoa. Pferdeheilkunde 22: 193-200. 
Kikuchi K, Kashiwazaki N, Nagai T, Noguchi J, Shimada A, Takahashi R, Hirabayashi M, Shino M, Ueda M, Kaneko H. 1999. Reproduction in pigs using frozen-thawed spermatozoa from epididymis stored at $4{ }^{\circ} \mathrm{C}$. Journal of Reproductive Devevelopment 45: 345-350.

Len JA, Jenkins JA, Eilts BE, Paccamonti DL, Lyle SK, Hosgood G. 2010. Immediate and delayed (after cooling) effects of centifugation on equine sperm. Theriogenology 73: 225-231.

Martinez-Pastor F, Anel L, Guerra C, Alvarez M, Soler AJ, Garde JJ, Chamorro C, de Paz P. 2006. Seminal plasma improves cryopreservation of iberian red deer epididymal sperm. Theriogenology 66: 1847-1856.

Moore AI,Squires EL, Graham JK. 2005. Effect of seminal plasma on the cryopreservation of equine spermatozoa. Animal Reproduction 63(9): 2372-2381.

Pickett BW, Sullivan JJ, Byers WW, Pace MM, Remmenga EE. 1975. Effect of centrifugation and seminal plasma on motility and fertility of stallion and bull spermatozoa. Fertility and Sterility 26: 167-174.

Pilch B, Mann M. 2006. Large-scale and high-confidence proteomic analysis of human seminal plasma. Genome Biology 7: R40.

Rijsselaere T, Van Soom A, Macs D, de Kruif A. 2002. Effects of centrifugation on in vitro survival of fresh diluted canine spermatozoa. Theriogenology 57: 1669-1681.
Rota A, Magelli C, Panzani D, Camillo F. 2008. Effect of extender, centrifugation and removal of seminal plasma on cooled-preserved Amiata donkey spermatozoa. Theriogenology 69: 176-185.

Schäfer-Somi S, Kluger S, Knapp E, Klein D, Aurich C. 2006. Effects of semen extender and semen processing on motility and viability of frozenthawed dog spermatozoa. Theriogenology 66: 173-182.

Suzuki K, Asano A, Erikkson B, Niwa K, Nagal T, Rodriquez-Marlinez H. 2002. Capacitation status and in vitro fertility of boar spermatozoa: effects of seminal plasma, cumulus-oocyte-complexesconditionned medium and hyaluronan. International Journal of Andrology 25: 84-93.

Töpfer-Petersen E, Ekhlasi-Hundrieser M, Kirchhoff C, Leeb T, Sieme H. 2005. The role of stallion seminal plasma proteins in fertilisation. Animal Reproduction Science 89: 159-170.

Vadnais ML, Kirkwood RN, Specher DJ, Chou K. 2005. Effects of extender, incubation temperature, and added seminal plasma on capacitation of cryopreserved, thawed boar sperm as determined by chlortetracycline staining. Animal Reproduction Science 90: 347-354.

White IG. 1993. Lipid and calcium uptake of sperm in relation to cold shock and preservation. A Review. Reproduction Fertility and Development 5: 639-658. 